\title{
Flying in Clear Skies: Technical Arguments Influencing ANAC Regulations*
}

\author{
Marcelo Fragano Baird \\ PhD candidate in Political Science, Universidade de São Paulo, Brazil \\ Ivan Filipe de Almeida Lopes Fernandes \\ PhD candidate in Political Science, Universidade de São Paulo, Brazil
}

\begin{abstract}
Regulatory agencies possess the particularity of being controlled by non-elected politicians whose power is derived from delegations made by incumbent powers. There exists, however, a concern with the creation of institutional mechanisms that permit public participation, thus guaranteeing greater democratization and social control of the regulatory process. One of these participatory mechanisms is the public hearing, which was not given much attention by Brazilian literature on lobbying and interest groups. This article seeks to contribute to fill this gap, focusing on the impact of interest groups acting upon the National Civil Aviation Agency, ANAC. Analyzing comments sent to the public hearings, we identified the commentators and the intensity of their participation, the impact of their efforts as measured by the rate of comment incorporation, and we explained why some comments are incorporated and others are not. We organized an original data base of the comments made at all ANAC public hearings between 2007 and May 2012. We analyzed 518 comments concerning 48 regulations. To test participant influence, we classified the comments by degree of technicality, economic or legal argument, authorship, and request for regulation. To understand the incorporation process, we used regression models through which we presented evidence that a comment's incorporation is directly related to its degree of technicality. Technical comments, which effectively subsidize the resolution, have a higher chance of being incorporated. Even more than corporate power or its force of participation, the technical quality proved to be the main factor for comment incorporation.
\end{abstract}

Keywords: Public hearing; social participation; regulatory agencies; ANAC; lobby.

(*) http://dx.doi.org/10.1590/1981-38212014000100012

The replication dataset can be found in bpsr.org.br/files/arquivos/Banco_Dados_Baird_Fernandes.html

The authors would like to note their sincere appreciation to Mauro Calvin for his incredible support during the data collection. Any errors that may exist are the entire responsibility of the authors. 


\section{Introduction}

aily, we see information in the press regarding health plans, telephone and energy rates, the prohibition of medicines, etc. What do these themes have in common? They are all regulated by federal regulatory agencies. Created in the mid-1990s in the midst of the state reform process, the regulatory agency is an important institutional innovation. Among its main characteristics is the existence of institutional mechanisms to enable and encourage social participation and control.

One of these participation mechanisms is the public consultation, whereby groups can send contributions to the regulatory agencies in respect to regulation projects. If we combine this move towards social participation with the growing impact which measures adopted by these agencies generate in society, it is expected that the groups will articulate to try to influence the formulation of regulation in their favor (BAIRD, 2012). It is important to note, however, that regulatory agencies do not have a legal obligation to institute public hearings (ALVES, 2008). However, the performance of consultations is customary, at least for polemic themes that affect important interests.

Despite the importance of the subject, little attention has been given at these hearings to the interest group's political actions upon regulatory agencies. Most studies seek to analyze the relationship between agencies and other instances of Executive Power (PÓ, 2009; SILVA, 2011a; SILVA, 2011b). On the other hand, studies of interest group lobbying tend to focus on other political arenas, principally National Congress (CABRAL, 2007; MANCUSO, 2007; TAGLIALEGNA and CARVALHO, 2006). The present analysis seeks to fill in this gap, driving its attention to the impact of interest group performance upon the National Civil Aviation Agency, ANAC. For this, we analyzed comments sent during all public hearings ${ }^{1}$ since the creation of the agency in $2006^{2}$.

In taking on this study, we had three basic objectives: the first was to identify types of commentators participating in public hearings and their intensity; secondly, we strove to evaluate the impact of the group's performance through their contributions. Finally, we attempted to explain why these comments were incorporated into the final text of the regulation. The agencies have a discretionary power over the resolutions to be adopted, reserving the right to incorporate, or not, the proposed comments into the final version of the regulation.

The article is divided into six sections, including the introduction. Next, we present literature about interest groups and bureaucracy, introducing the discussion about regulatory agencies. In the third section, we analyze the role of the public hearings and we broach the research hypothesis. In the fourth section we present the research methodology, with the presentation of our data and estimation methods. In the fifth section, we present the

1 We should clarify that regulatory agencies often establish differences between the public consultations and the public hearings. The former provides the possibility of sending written contributions, whereas the latter refers to physical presence at the session. Differently from other hearings, ANAC does not distinguish between these two mechanisms. In this manner, we use the term public hearing to refer to the process of allowing general participation by the population through written comments, as well as the sessions requiring presence whose discourses were transcribed and used as input at the regulatory agency discussions.

2 ANAC, the only regulatory agency created during the presidential term of Luís Inácio Lula da Silva, was the last federal regulatory agency to be instituted. 
empirical results. Finally, in the sixth section, we conclude by summarizing the main findings and proposing new avenues to be pursued to better understand the role of interest groups in Brazilian regulatory agency decision-making processes.

\section{Interest groups and bureaucracy}

Articles about interest groups always emphasize the effects of the political actions of these groups upon Congress. However, during the second half of the last century, important governmental functions were transferred to governmental agencies linked to the Executive Power, charged with detailing and executing the laws. These agencies became important actors in the State political-institutional architecture and were responsible for complex tasks, providing services or regulating private activity (FERNANDES, 2011 and PETERS, 1995). During the last decades, ten times more regulations were produced by governmental agencies than the number of laws approved by Congress (COGLIANESE, 2004, p.05 apud YACKEE and YACKEE, 2006). Despite this major transformation, few efforts have been made in the theoretical field to account for this new political-institutional framework.

Three theoretical discussions began dealing early on with the effects of interest group political actions upon governmental agencies, becoming, therefore, references for debates in this area: discussion about forms of intermediation relations between interest groups and the government, studies of policy subsystems and regulation economic theory.

Classical studies performed on the Brazilian case embark on the analysis of relationship patterns between the government and interest groups, using concepts such as clientelism, bureaucratic rings and corporatism (CARDOSO, 1975; DINIZ and BOSCHI, 2004; NUNES, 1997; SCHMITTER, 1971). Although enlightening, and with an extremely keen perception of the Brazilian political reality, these studies were less interested in pursuing a systematic empirical analysis of the interest group's actions than in constructing a typology of public-private interaction in Brazil.

Policy subsystem studies gave a highlighted role to the effect of interest group's actions upon governmental agencies, mapping the relationships between the principal actors in certain areas of public policy. These studies sought to make a diachronic analysis of the public policies beginning with the relations established between interest groups, agencies and Congress, forming what has become known as the iron triangle (FRITSCHLER, 1969; HECLO, 1978). It is noted, therefore, that Congress still performs an important role within this theoretic lineage. Although regulatory agencies participate in the analytical framework, the analysis focuses on the understanding of the political macro processes and the description of the main events related to public policy.

In the beginning of the 1970s, the seminal work of George Stigler (1975) gave rise to the theory of economic regulation, often called capture theory. The theory of economic regulation formally modeled a relationship system between politicians and interest groups linked to industry: the interest groups needed regulations to protect themselves from market competition, while the politicians offered these regulations. A balance was reached from common interests: the groups obtained protection to survive on the market with the creation of entrance barriers for new competitors, while the politicians obtained financial support to keep their party machine alive and to gain votes.

This was the first theoretical body to specifically treat the relationship between interest groups and agencies. In spite of their theoretical contributions, the models did not allow the 
empirical and theoretical analysis of how the mechanisms and nuances of the group's concrete actions affected the interaction between groups and regulatory agencies. It is interesting to note that, except for a few case studies (MOE, 1985; SELZNICK, 1949), "surprisingly little empirical work has been done on the role of interest groups in administrative policymaking" (BAUMGARTNER and LEECH, 1998, p. 145).

The point which caught the attention of Baumgartner and Leech is particularly surprising in the USA, in that the country's legislation already foresaw a formal participation mechanism for groups in the formulation of agency regulations since 1946: the Administrative Procedures Act (APA), which obliges regulatory agencies to publish all proposed legislations in the Federal Register (the equivalent of Brazil's Diário Oficial) and to open a period for the receipt of written contributions from the interest groups (notice and comment period). Only after analysis of the comments can the regulatory agencies define the final content of the legislation to be effectively adopted.

This was exactly "the path taken by many authors, beginning in the 1990s, seeking to measure the group's influence on agency decisions through observation of the suggestions made on proposed resolutions" (BAIRD, 2012, p. 65). The pioneer study was performed by Golden (1998). The methodology employed by the author was innovative and of great heuristic value since, focusing on this rich source of information, it could measure the real impact of interest group contributions on regulatory agency legislation, thereby permitting a more accurate and concrete evaluation of the interest group's lobbying during an important phase of the decision process.

One of the principle forms of lobbying is the provision of technical information to bureaucrats who are responsible for the formulation and implementation of public policies. In this sense, public consultations become a valuable tool for observing the impact of the interest group's actions on bureaucracy, since the moment of interaction between the interest groups and bureaucracy is formal and documented, enabling empirical analysis of the lobby on bureaucracy.

Golden (1998) collated the beginning and final versions of 11 resolutions promulgated by three regulatory agencies and observed whether or not the changes corresponded with the contributions. Assuming that the changes had occurred as a result of the comments, the author could verify if the interest groups had influence or not. Various authors took the same path, adopting similar methodology and observing the content and the type of participation at the public consultations (BALLA, 1998; WEST, 2004).

Susan Yackee (2005) adopted this new perspective, but brought greater methodological sophistication to encompass a broader list of resolutions and obtain results that are likely more generalized. The author united more than one thousand contributions from approximately forty regulations and performed inferential analysis, not merely descriptive, to assess the impact of the comments on the final versions of the resolutions. The author observed that regulatory agencies altered their resolutions to better correspond with the average positioning of the commentators during the period of the public hearings.

Despite the problems relative to this type of analysis, with the difficulties of codifying the changes which occurred (WEST, 2005) and the absence of contextual variables that could help explain the final policy outcomes (BAIRD, 2012), Yackee's study (2005) opened new doors for literature, especially for those interested in obtaining generalized results for a broader population of public consultations.

Yackee and Yackee (2006) analyzed the business bias in the incorporation of nearly 1700 comments regarding 30 regulations by four government regulatory agencies. Kelleher and Yackee (2006) observed informal contacts - phone calls and personal meetings - conducted by legislators, 
governors and interest groups in an attempt to influence regulatory agencies. To do so, they relied on surveys conducted with decision-makers from about 80 regulatory agencies in the 50 U.S. states. Yackee and McKay (2007) studied the effects of competition among interest groups in lobbying the regulatory agencies. Their sample was based on 1700 comments on 40 regulations.

Naughton, Schmid, Yackee and Zhan (2009) evaluated the importance of interest group participation in the early stages of decision-making. Analyzing approximately 500 comments coming from 36 regulations concerning the Department of Transportation, the authors concluded that contributions made early in the process affect the final adopted text. Yackee and Nelson (2011) studied the role of coalitions in influencing the regulatory agencies. From the combination of data from surveys conducted with entities that lobby and analyze content concerning seven regulatory agencies, the authors found evidence of coalition effectiveness in impacting the approved regulations.

The debate regarding interest group actions with regulatory agencies in Brazil began taking greater form, beginning with the creation of regulatory agencies in the mid-1990s and with the increasing presence of formal mechanisms for popular participation, such as public consultations and hearings. Despite the absence of a single law governing their operation, all national regulatory agencies have mechanisms for popular participation.

The primary focus of this study, however, was something else. The process of creation and institutional evolution of regulatory agencies gave rise to a profusion of works that sought to understand the political game behind their formation and institutional design (BAIRD, 2011; NUNES, 2001; NUNES et al, 2007; PIOVESAN, 2002). Others sought to discuss the rationality of the model vis-à-vis the executive agencies (COSTA, 2002; PACHECO, 2006). Mechanisms for civil society participation and accountability present in the agencies model were studied by Pó (2004) and Pó and Abrucio (2006).

Despite the diversity of studies, the main debate concerns the independence of regulatory agencies and the control mechanisms available to the elected government to oversee the actions of regulatory bodies (PÓ, 2009; SILVA, 2011a; SILVA, 2011b). These studies analyze the action of the government itself, and not the actions of the interest groups. As pointed out by Baird (2012), one can, "roughly distinguish between two possible areas of focus for regulatory agencies: one focuses on the key actors of the state and the other focuses more closely on the actions of interest groups" (BAIRD, 2012, p.71).

This second focus, though less widespread, was also covered by national literature, with studies that sought to follow the actions of interest groups through contributions made during the public consultations (ALVES, 2008; MATTOS, 2004; SILVA, 2012). These studies aim to describe the participants in the public consultations at the National Telecommunications Agency - ANATEL, the National Electric Energy Agency - ANEEL, and the National Health Surveillance Agency - ANVISA, analyzing the incorporation rate of the comments made by these actors, so as to assess the potential influence exercised by these groups.

Studies performed by Mattos (2004) and Alves (2008) analyzed about a dozen ANATEL and ANVISA resolutions, respectively, and demonstrated that the interests of the groups are relatively contemplated: in both cases, the incorporation rate of contributions was approximately $25 \%$.

The work of Silva (2012) was more comprehensive, covering all of the ANEEL resolutions in public hearings between 1998 and 2006. The authors sought to compare the incorporation of comments made by business interest groups vis-à-vis consumers. Their main hypothesis, based on the ideas of Olson (1999) and Stigler (1975), was related to a relatively greater acceptance of comments made by the regulated sector. The conclusion points to a greater favoritism of corporate groups, although the percentage difference is minimal. 
These studies, of a more descriptive character, represent important efforts to use the regulatory agencie's popular participation mechanisms to understand the influence exercised by interest groups. In line with the seminal study by Golden (1998), it was possible to observe who participates the most at public consultations and which group's comments are considered. However, the methodology used was not sufficient to explain why certain contributions are more heeded than others by the regulatory agencies. It is upon this challenge that we focus our work.

\section{Interest group influence at public hearings}

Economic regulation theory attributes an important role to interest groups, but the analyses do not take into consideration the complexity of the political phenomenon. The positive theory of institutions (MOE, 1987) sought to broaden the discussion by identifying the principal-agent problems in the regulatory process. They sought, therefore, to establish more direct connections between social interests and political outcomes. The theoretical focus was on the mechanisms available to those in office to control public bureaucracy, whose need for supervision would therefore arise from the necessity to delegate power and from the relative autonomy of the bureaucrats (WEINGAST and MORAN, 1983).

The first focus of study was to understand how the American Congress controls the activities of regulatory agencies (CARRIGAN and COGLIANESE, 2011; WEINGAST and MORAN, 1983). There are several ways to exercise this control, the most direct being the approval of detailed laws, in order to reduce the space for autonomous bureaucrat decisions (KERWIN, 1996). The executive branch also appears as a competitor in the quest for control of the regulatory agencies, providing some means of supervision. It is thus possible to observe progress in relation to the theory of economic regulation, in that the importance of institutions and political actors was highlighted, showing how institutional mediations affect the way in which social interests are reflected, at the end of the day, in public policies.

However, putting too much focus on institutions, this neglected the direct political actions of the interest groups. This action is not restricted to the election period, via bid presentations or campaign financing. Interest groups are organized and perform permanent and direct lobbying to these powers, including via public hearings. Kerwin (1996) was direct in his criticism: "Interest groups are not considered the major players, but profoundly influence these other institutions." (KERWIN, 1996, p. 297). You can therefore see that "what occurred in theories concerning regulation was a pendulous movement that went from one extreme of emphasis on social interests to another extreme, that of emphasis on institutions interests, without being able to articulate a more coherent theory that would account for balancing interests and institutions " (BAIRD, 2012, p. 61).

It is clear, therefore, that studies with a more empirical foundation about the actual influence exercised by interest groups are greatly valued. It is worth emphasizing that although the neoinstitutionalism literature has considered the regulatory agencie's participation mechanisms, their focus was to observe the way in which the "principals" - the executive and legislative powers - maintained control over the bureaucracy, slowing its discretionary momentum. According to this logic, the groups who feel affected by the regulatory agencies would use the public hearings to make sure that their opposition is made known to these powers. Once alerted, the "principals" could pressure the bureaucracy and define the decision to be made.

Thus, it is important to adopt another theoretical perspective on this regulatory moment, to allow the accurate analysis of interest group's influence on the regulatory agencies. This work seeks to contribute to the effort to fill this gap by analyzing the impact of contributions 
from interest groups at all ANAC public hearings between 2007 and 2012. Our work also seeks to advance in relation to Brazilian literature on the subject, in that it presents and seeks to test some hypothesis which explain the motivation for regulatory agencies to incorporate certain comments over others.

The first way to qualify the comments is to divide them into technical and non-technical categories. It is possible that technical reviews tend to be incorporated by the regulator, since they provide information that may not have been evaluated during the preparation of the draft resolution. Furthermore, we classify the arguments presented in the comments as economic or legal. With that, we seek to find out if the regulatory agency is more sensitive to a particular type of argument. Finally, we analyze whether the comment calls for more or less regulation.

The introduction of these variables that qualify the comments made is relevant because a higher comment incorporation rate may be related to an increased production capacity of more informative comments, warning of economic, political or legal consequences of the resolution in question. It is possible that a group has a higher comment incorporation rate because of producing qualified comments and analyses concerning the resolution and not because of possessing greater influence on ANAC.

We propose the following research hypothesis:

Hypothesis 01: Technicality of the comments: agencies tend to incorporate more technical comments than non-technical comments.

In the context of this hypothesis, the public hearing would be a time to improve resolutions. The comments serve to increase the information available to the regulatory agency and improve the quality of the resolution. The regulatory agencies opened public hearings aiming at obtaining feedback from stakeholders. Moreover, during the public hearings, mere political pressure, when unqualified, would not produce large effects. The victorious arguments are precisely those that would shed light on new information relevant to the regulatory agency.

An important note concerning this point: by distinguishing between technical and non- technical comments, we do not claim, in any way, that technical comments put forth by any interest group could be neutral and therefore devoid of political interest. Comments from all groups are politically motivated, in the sense of being based on interests about how the benefits resulting from new resolutions should be distributed among different social groups. Thus, when dealing with technical comments, we are just pointing to the fact that some comments have the power to contribute more information pertaining to the topic addressed by the regulatory agency, when examining issues in a sophisticated and detailed manner, basing their positions and proposals on technical information and/or statistical data.

Hypothesis 02: Economic comments: agencies tend to incorporate comments that present economic arguments.

During the public hearings, mere political pressure, when unqualified in economic arguments, would not have a major effect during this time of decision-making. The arguments that tend to be victorious are precisely those that produce information and warnings about potential economic risks to the regulated sector. This is because ANAC would be sensitive to the economic interests at stake during their decision-making process and would avoid increasing costs to stakeholders when their decisions would affect the performance of the sector. 
Hypothesis 03: Legal comments: agencies tend to incorporate comments presenting legal arguments.

During the public hearings, mere political pressure, when unqualified in legal arguments, would not have a major effect during this time of decision-making. The arguments that tend to be victorious are precisely those that produce information relevant to the regulatory agency, including warnings that the resolution violates national or international law, signaling future court battles if it is not modified. Threats of legal retaliation would raise the costs for the regulatory agency of changing the bill.

Hypothesis 04: Power of business groups: businesses and business groups tend to get better results at public hearings.

Business interest groups are more organized and possess more resources to put pressure on regulatory agencies, besides being able to count on other pressure mechanisms. Based on collective action problems analyzed by Olson (1999), we know that the formation and operations of various groups in society are not symmetrical or balanced. The organizational and action capacity of small groups gives them a disproportionate power in relation to latent groups, in such a manner that these tend to benefit more in detriment to large social groups with common interests, but without the incentive to mobilize. The business groups would naturally be a group benefiting from a larger organization capacity, in that they are composed by a smaller number of parties.

Hypothesis 05: Business groups produce better comments: companies and business groups tend to have better results at public hearings because they produce better-qualified comments, offering the regulatory agencies arguments that corroborate and justify their interests.

In the event that the more incorporated comments are the technical comments and business groups are the most privileged groups in ANAC public hearings, we intend to see if this relationship is enhanced when interacting. That is, if the comments actually incorporated are the technical comments from the business community. The logic behind this hypothesis is the same that explains Hypothesis 4, nuanced by the fact that ANAC does not answer any comment from the business community except those which are justified in a technical manner, although they do not give the same attention to technical arguments from other non-business groups.

\section{Methodology}

Our research design does not seek to exhaust the explanations regarding why the ANAC resolutions take one form or another, answering to these or those interests. Surely, there are other mechanisms to pressure regulatory agencies. This can occur both directly but informally, with contact with the directors of the regulatory agencies, and indirectly, when interest groups mobilize other powers and/or other regulatory agencies of the Executive Branch to make contact with the regulatory agencies (YACKEE, 2005). Nor are we concerned with understanding how the topics covered by these resolutions entered the political agenda of the regulatory agencies while other, equally-important issues did not (BACHARACH and BARATZ, 1962), since mechanisms that explain the selection of topics to be regulated are beyond the proposed search method. Our goal, more modest, is to consider the action of 
interest groups exclusively during the public hearing, seeking to understand the causes that explain the influence exercised during this specific moment of decision-making.

\section{Data}

The analysis will be made from an original database on the comments made at the ANAC public hearings held between 2007 and 2012. The basic unit of analysis is the comment, and this refers to the set of propositions made by a specific actor regarding the proposed regulations at ANAC public hearings.

The choice of the unit of analysis is due to the fact that the responses made by ANAC on the incorporation or not of the contributions made at their public hearings are not uniform. In some reports, the considerations are made in relation to the comments of each of the actors; in other reports, the comments are divided into propositions and considerations are made for each of the propositions, organized into sets of similar propositions and in reference to specific articles and paragraphs of the regulations. Thus, when interest groups showed different documents in the same public hearing, these are considered as parts of the same comment.

In all, we analyzed 518 comments concerning 48 regulations. In the table below, we show the number of resolutions per year receiving comments and the number of comments made each year. To test the relative influence of the participants in the public hearings, we classify the comments according to the following variables: 1)incorporation of comment; 2)comment technicality; 3) economic argument; 4)legal argument; 5)comment authorship; 6)demand for regulation.

An analysis of comment contents by variable codification was carried out by three coders.

We adopted similar criteria to those used in the North American literature on participation in regulatory agencies public hearings. Like us, Golden (1998), West (2005), Yackee (2005) and Yackee and Yackee (2006) used content analysis to transform the comments and resolutions into quantitative data. This is because content analysis is "a research technique for making valid and replicable inferences from data" (KRIPPENDORFF, 1980, p. 21 apud YACKEE and YACKEE, 2006).

To estimate the reliability of content analysis realized by the three distinct coders, we determined that some regulations would be analyzed by two of the three coders, which allowed the evaluation of the method's strength by evaluating the Pearson correlation coefficient. Of 48 regulations, 15 were analyzed by two coders.

Table 1. Resolutions and comments by year

\begin{tabular}{ccc}
\hline Year & No regulamentations & No comments \\
\hline 2007 & 02 & 31 \\
2008 & 03 & 44 \\
2009 & 20 & 219 \\
2010 & 14 & 185 \\
2011 & 06 & 32 \\
2012 & 03 & 07 \\
Total & 48 & 518 \\
\hline
\end{tabular}

Source: Dataset: Banco_Dados_Baird_Fernandes 
The rules for the encoding used in the research were as follows:

The variable incorporation measures whether the comment was incorporated or not.

We assign the value of 0 when the comment is not incorporated, 1 when it is considered appropriate and submitted for future analysis and 2 when it is effectively incorporated and changes the final resolution. Partial attention to the comment is assigned the value of 2 , to the extent that the final version of the resolution is changed. ANAC itself indicates the incorporation status of the comment.

The variable technicality measures the technical quality of the comment. The value of 0 is assigned when the comment is not technical, 1 when the comment shows some knowledge of the matter by the commentator, but no comprehensive assessment, and 2 when there is a thorough analysis of the issue, including the submission of data to add to the debate. To check the validity of the results, two other measures of technical quality of comments were made: the number of words and number of proposals for change. A greater number of words generally indicate a greater technical capacity to discuss the matter in the same way that the proposals for change usually mean prior detailed knowledge on the subject.

The variable economic comment indicates whether the comment is an economic theme or argument, or not. We assign the value of 1 when the argument is of an economic nature and 0 if it is not. The economic argument concerns the requests for changes due to the fact that the resolutions affect the economic sector. The same goes for the legal comment variable. The value of 0 is assigned when the argument is not legal and 1 when it is. The legal argument refers to requests for changes of the resolutions because of their inconsistency with rules and national and/or international laws.

The variable request for regulation measures if the comment asks for more or less regulation. When the comment requested a move towards greater regulation, it was assigned a value of 1 . When the comment requested a change towards lesser regulation, it was assigned a value of -1 . When the comment did not request a change in the level of regulation, it was assigned a value of 0 . Finally, the variable comment author indicates the type of interest group to which the commentator belongs. There are six distinct types of commentators: i) public institutions; ii)individuals; iii)companies; iv)business associations; v)labor unions; and finally, vi)civil society organizations. Our categories are mutually exclusive and exhaustive, and the vi type is residual.

\section{Reliability of variables}

Table 2 shows data reliability through the Pearson correlation coefficient for each of the variables obtained from the comparison of variable assignments made by each of the independent coders, taken in pairs ${ }^{3}$. As we see in Table 2, the data has satisfactory reliability indices. All variables have correlations higher than 0.5 and the main variable of interest, incorporation, has an index greater than 0.88 . Moreover, all are significant. The average reliability of the database is 0.8313 and if we exclude the variables number of words and number of proposals for change, the average reliability is 0.790 . 
Table 2. Reliability of variables

\begin{tabular}{cccc}
\hline Variables/codificators & $\mathrm{AB}$ & $\mathrm{AC}$ & $\mathrm{BC}$ \\
\hline Incorporation & $0.888^{* *}$ & $0.941^{* *}$ & $0.935^{* *}$ \\
Technicality & $0.823^{* *}$ & $0.723^{* *}$ & $0.540+$ \\
Words & $0.999^{* *}$ & $0.953^{* *}$ & $0.728^{* *}$ \\
Proposals & $0.972^{* *}$ & $0.958^{* *}$ & $0.995^{* *}$ \\
Economic & $1.00^{* *}$ & $0.840^{* *}$ & $0.685^{*}$ \\
Legal & $0.780^{* *}$ & $0.734^{* *}$ & $0.595+$ \\
Regulation & $1.00^{* *}$ & $0.683^{* *}$ & $0.677^{* *}$ \\
\hline
\end{tabular}

Pearson's correlation: $\mathrm{p}$ - value $<0,05(+) ;<0,01^{*}$ and $<0,001$ (**). $^{* *}$.

Source: Dataset: Banco_Dados_Baird_Fernandes

\section{Methods}

In the next section, we analyze the data indicating which interest groups contributed the most and which type of comments were most commonly made. Then, we analyze their respective rates of incorporation and, finally, which variables are related to the incorporation of comments, through regression analysis of binary data and multi-categorical data. When the dependent variable is 0 or 1 , we use logistic regression models, and when the dependent variable is 0,1 and 2, we use ordered logistic regression models. In all these, we present strong standard errors clustered by regulation.

The logistic models causes results predicted by the estimated model to be between 0 and 1 , thereby estimating the probability that the event $(Y=1)$ occurs. In turn, the ordered logistic models are appropriate when the dependent variable has more than two categories and the values of each category have a natural sequential order. This is because the values assigned to the variables are not arbitrary, but the interval difference is not equal to each interval. That is, the 2 does not represent a value that is twice 1 (WOOLDRIDGE, 2002, p. 504).

\section{Econometric model}

The ordered logistic model is the more general of the two proposed estimations therefore we define our estimation technique only using this model. The binary logistic model is a special case of the former. In both, $\mathrm{y}$ (conditioned on independent variables $\mathrm{x}$ ) can be derived from a latent variable model.

Assuming that the latent variable $y^{*}$ is determined by the process (WOOLDRIDGE, 2002, p. 505):

$$
y^{*}=x \beta+e ; \quad e \mid x \sim \operatorname{Normal}(0,1)
$$

where $\beta$ is $\mathrm{Kx} 1$ and $\mathrm{x}$ does not have a constant. And $\alpha 1<\alpha 2<\ldots<\alpha \mathrm{j}$ are separation parameters that define: 
(2)

$$
\begin{aligned}
& y=0 ; \text { if } y^{*} \leq \alpha 1 \\
& y=1 ; \text { if } \alpha 1 \leq y^{*} \leq \alpha 2 \\
& (\ldots) \\
& y=j ; \text { if } y^{*}>\alpha j
\end{aligned}
$$

\section{Estimation}

The parameters $\alpha \mathrm{i}$ and $\beta \mathrm{i}$ are estimated by maximum likelihood by the function of loglikelihood (WOOLDRIDGE, 2002, p. 506).

$$
\begin{aligned}
L_{i}(\alpha, \beta) & =1\left[y_{i}=0\right] \log \left[\Lambda\left(\alpha 1-x_{i} \beta\right)\right]+1\left[y_{i}=1\right] \log \left[\Lambda\left(\alpha 2-x_{i} \beta\right)-\Lambda\left(\alpha 1-x_{i} \beta\right)\right]+\ldots \\
\ldots & +1\left[y_{i}=j\right] \log \left[1-\Lambda\left(\alpha_{j}-x_{i} \beta\right)\right]
\end{aligned}
$$

\section{Who participates and how}

Our first interest is to observe the relative degree of participation in public hearings.

To do so, we show how many comments were made by each of the interest groups, divided into four categories: the business community, consisting of companies and business associations; state actors; individuals; and civil society representatives, composed of trade unions and non-governmental organizations. As the reviews vary in the number of propositions and in length, we also present the comparison according to these variables.

The most participatory group is the business community group, with over $50 \%$ of the comments, $68 \%$ of the proposals and $70 \%$ of the words sent. In absolute numbers, the business community presented 263 of the 518 comments, 1599 of the 2345 proposals and 433,280 of the 618,481 words. Far behind the business community, individuals are the second most significant group, reaching $30.7 \%$ of the comments made, $14.5 \%$ of the proposals and $11.2 \%$ of the words, indicating therefore that, although its gross share is relatively large (159 of 518 comments), their comments are less sophisticated than those made by the business community.

The third most participatory group is made up of state actors who are responsible for approximately $10 \%$ of the comments, $12 \%$ of the proposals and $14 \%$ of the words. And finally, the fourth and least-participative group is made up of representatives of organized civil society and non-governmental organizations and trade unions, which have reached very low levels of comments made: $8 \%$ of comments, $5 \%$ of the proposals and $5 \%$ of the words.

These results are shown in Table 3:

Table 3. Participation in ANAC public hearings

\begin{tabular}{ccccccc}
\hline Participation & \multicolumn{2}{c}{ № comments } & \multicolumn{2}{c}{ № proposals } & \multicolumn{2}{c}{ № words } \\
\hline Public actors & 54 & $10.4 \%$ & 285 & $12.2 \%$ & 87274 & $14.1 \%$ \\
Individuals & 159 & $30.7 \%$ & 339 & $14.4 \%$ & 68967 & $11.1 \%$ \\
Business community & 263 & $50.8 \%$ & 1599 & $68.2 \%$ & 433280 & $70.1 \%$ \\
Civil society & 42 & $8.1 \%$ & 122 & $5.2 \%$ & 28960 & $4.7 \%$ \\
Total & 518 & $100 \%$ & 2345 & $100 \%$ & 618481 & $100 \%$ \\
\hline
\end{tabular}

Source: Dataset: Banco_Dados_Baird_Fernandes 
If we analyze this data with reference to the size of the comments as a way of measuring their technicality, the result remains quite favorable for the business community. The relative amount of words and proposals per comment is much higher in corporate participation. However, in this regard, the difference between business community comments and those of state actors is significantly lower. It is therefore not possible to indicate that business community comments are technically superior to those of the state actors. On the other hand, the relative length of the comments from these two groups is about 2-3 times greater than the relative length of comments from individuals and representatives of organized civil society, namely 2.25 times greater when the length is measured in number proposals and 2.91 times higher when it is measured in number of words. The data are presented in Table 4 below.

We compared the findings in Table 4 with the measurement taken by the technicality variable that assigns values of 0 when the comment is not technical, 1 when the comment demonstrates knowledge of the matter but without being an exhaustive review and 2 when there is a thorough review. In Table 5, we display the absolute values and the average technicality of the comments made by the respective types of groups. The same pattern repeats itself, which is a good indication of the validity of the technicality variable ${ }^{4}$. Comments from the public sector actors and the business sector actors are still much more technical than the other comments. We can also observe that all interest groups tend to mostly present comments that reflect knowledge of the issue, without providing a thorough evaluation. On the other hand, only the business community sector and the public sector tend to present sophisticated comments that thoroughly evaluate the regulated issue more often. These two groups rarely (about $15 \%$ of the time) present non-technical reviews, while this happens more often in the comments from civil society representatives and individuals (31\% and $48 \%$ of the time, respectively).

Table 4. Relative length of comments

\begin{tabular}{ccc}
\hline Participation & Per proposal & Per words \\
\hline Business community & 6.08 & $1,647.45$ \\
State actors & 5.28 & $1,616.19$ \\
Individuals & 2.13 & 433.75 \\
Civil society & 2.90 & 689.52 \\
All groups & 4.53 & $1,193.98$ \\
\hline
\end{tabular}

Source: Dataset: Banco_Dados_Baird_Fernandes

Table 5. Comments by technical level

\begin{tabular}{|c|c|c|c|c|}
\hline Interest groups & Not technical & $\begin{array}{l}\text { Knowledge of the } \\
\text { issue }\end{array}$ & $\begin{array}{l}\text { Exhaustive } \\
\text { assesment }\end{array}$ & Average \\
\hline State actors & 08 & 29 & 17 & 1.17 \\
\hline Business community & 40 & 166 & 57 & 1.06 \\
\hline Civil society & 13 & 25 & 04 & 0.79 \\
\hline Individuals & 76 & 78 & 05 & 0.55 \\
\hline Total & 137 & 298 & 83 & 0.90 \\
\hline
\end{tabular}

Source: Dataset: Banco_Dados_Baird_Fernandes

4 Another indication of the validity of this variable is the correlation with the number of words logarithm and with the number of proposals for change logarithm (+1), namely: 0.7071 and 0.5752 . 
Finally, we will analyze whether or not the comments use economic and legal arguments. We do this in Table 6 and Table 7. In Table 6 we find that the actors, with the exception of the business community, do not use economic arguments. While $30 \%$ of the business communitie's comments used economic arguments, only $16.7 \%$ of the organized civil societie's comments did. The rate of economic comment utilization was $13 \%$ in the public sector, while economic comments made by individuals occurred less than $5 \%$ of the time. In Table 7, we find that the sector that most uses legal arguments is the public sector; the use of this type of argument occurs in no less than $37 \%$ of the comments. The business community makes use of legal arguments about $20.5 \%$ of the time, civil society $19 \%$ and individuals $12.6 \%$.

The above results demonstrate that ANAC public hearings constitute an arena in which technically-qualified business community interest groups have great influence. However, the low presence of organized civil society interest groups, individuals or public authority interest groups does not mean that they have more difficulties in having their arguments heard by the regulatory agency.

It is important to note that, although the business community interest groups are responsible for about $50 \%$ of the comments, it is impossible to define an ideal pattern for the participation of the different social groups. It is possible, therefore, that the $50 \%$ of participation of the other groups is a high number, given their limited access to organizational, financial and political resources to attend public hearings.

We will now discuss the aspects that influence the incorporation of comments. It would not be unlikely, for example, if the regulatory agency were to possess an anti-business bias, that other interest groups would possess higher rates of incorporation than the business community interest groups. This is what we will discuss in the next section.

Table 6. Economic argumentation

\begin{tabular}{cccc}
\hline Participation & Not economic & Economic & Proportion \\
\hline Business community & 184 & 79 & $30.0 \%$ \\
State actors & 47 & 07 & $13.0 \%$ \\
Civil society & 35 & 07 & $16.7 \%$ \\
Individuals & 152 & 07 & $4.4 \%$ \\
Total & 418 & 100 & $19.3 \%$ \\
\hline
\end{tabular}

Source: Dataset: Banco_Dados_Baird_Fernandes

Table 7. Legal argumentation

\begin{tabular}{cccc}
\hline Participation & Not legal & Legal & Proportion \\
\hline State actors & 34 & 20 & $37.0 \%$ \\
Business community & 209 & 54 & $20.5 \%$ \\
Civil society & 34 & 08 & $19.0 \%$ \\
Individuals & 139 & 20 & $12.6 \%$ \\
Total & 416 & 102 & $19.7 \%$ \\
\hline
\end{tabular}

Source: Dataset: Banco_Dados_Baird_Fernandes 


\section{Who influences}

The variable measuring the influence of the actors present at the ANAC public hearings is comment incorporation. The value is 0 when the comment is not embedded, 1 when the comment is considered relevant and ANAC agrees to review it in the future and 2 when it is incorporated and it effectively changes the final resolution. As we can see in the table below, the average incorporation rate of all comments is quite high, showing that the regulatory agency is fairly sensitive to commentator's arguments. Approximately $41 \%$ of the comments incorporated have at least part of their proposal incorporated by the regulatory agency. However, this rate is not similar for all groups. State actors and business group actors have a higher incorporation rate than individuals and civil society interest groups. The results are shown in Table 8 below.

Despite the fact that business community groups and state actors have higher incorporation rates, this does not mean that these actors are privileged by ANAC. As discussed in the previous section, the groups tend to have different types of comments, varying in terms of argument technicality or type of argument presented. Thus, it is necessary to make a multivariate analysis incorporating the variables that qualify the comments, so we can judge if the observed higher rate of incorporation for business community interest groups and state actors groups, as explained in Table 8, reflects a favoring by ANAC of those groups, or if it is merely due the characteristics of the submitted comments.

We used two regression models. In the first model, given the nature of the dependent variable trichotomy, we appraised ordered logistic models to check if the relationships found are valid for the two different answers given by ANAC: incorporation that alters the resolution and consideration of the result relevance for future analysis. In the second, we consider only the comment incorporation as an event, and the relevance, or non-incorporation, as a nonevent, so that the dependent variable becomes binary and logistic regression estimation is then appropriate. In both analyses, we first present models that include only interest groups dummies, and then incorporate the characteristics of the comments. Finally, we create interactions to see if specific types of comments are more accepted by ANAC when submitted by a particular set of interest groups.

Table 8. Incorporation of comments

\begin{tabular}{|c|c|c|c|c|}
\hline Participation & Non-incorporation & To be analyzed & Incorporation & $\begin{array}{c}\text { Rate of } \\
\text { incorporation }\end{array}$ \\
\hline State actors & 22 & 03 & 29 & $53.7 \%$ \\
\hline Individuals & 106 & 09 & 44 & $27.7 \%$ \\
\hline Business community & 118 & 15 & 130 & $49.4 \%$ \\
\hline Civil society & 25 & 07 & 10 & $23.8 \%$ \\
\hline Total & 271 & 34 & 213 & $41.1 \%$ \\
\hline
\end{tabular}

Source: Dataset: Banco_Dados_Baird_Fernandes 


\section{Ordered logistic model}

In Table 9 we present the results of the ordered logistic model to infer which interest groups have the most influence on ANAC resolutions in public hearings. In the first model, we identify the interest groups, having organized civil society as baseline (it therefore will not appear in the table). As can be seen in the first column, the comment indicator realized by an individual is not different from the baseline and will thus be removed from the base model, ready in the second column. Comment indicators made by business community interest groups and the public sector are positive and significant.

In the second model, we incorporate the variables that characterize the comments: technicality, economic, legal and regulatory. The results are quite interesting. The two commentator-type indicator variables lose significance and only the variable that indicates that the comment is technical proves to be statistically significant ${ }^{5}$. The results remain strong when measuring technicality by the number of words or proposals, as in Model 3 columns 4 and 5. In the fourth and fifth models, we verify if the relationship between technicality and interest group is stronger when the variables interact. That is, if ANAC is more responsive to technical arguments from the business community and/or public sector. Neither of the interactions was significant, indicating that ANAC does not respond differently to technical arguments coming from different types of interest groups.

Thus, the analysis indicates that no interest group takes precedence in ANAC public hearings. The highest incorporation rates of actors from the public sector and the business community do not appear to be justified by an alleged favoritism to those groups but rather by the very quality of the argument ${ }^{6}$.

We note, finally, that in some of the models presented, the difference between the categories comment is not incorporated and comment deemed relevant and to be considered in the future is not statistically significant (models 1, 4 and 5), and because of this, we redid the analysis, this time having a binary variable as a dependent variable that measures only the effective incorporation of the comment as an event, considering the other categories, therefore, as non-events. Using the basic function of Model 2, we observed that only the probability of non-incorporation (0) and incorporation (2) is affected by variation in the level of technicality, as can be seen in Figure $1^{7}$.

\footnotetext{
5 The same result stands if the technicality variable is computed as a dummy indicating that the comment is 0 (neither technical nor exhaustive) and 1 (exhaustive).

6 As a simple verification of the empirical findings, we re-did all analyses using the ordinary minimum squared estimator. Very similar results were obtained. Moreover, we re-did the analyses incorporating year dummies to eliminate specific impacts that had ocurred each year. Again, the results were quite similar.

$7 \quad$ The formulas used to construct the graph are the following: $\mathrm{P}(\mathrm{Y}=0)=1 /[1+\exp (\mathrm{X} \beta-\alpha 1)] ; \mathrm{P}(\mathrm{Y}=1)=\{1 /[1$ $+\exp (X \beta-\alpha 2)]\}-\{1 /[1+\exp (X \beta-\alpha 1)]\} ; P(Y=2)=1-[1 / 1 \exp (X \beta-\alpha 2)]$. For the other variables present in the model, we will consider the average values
} 
Table 9. Incorporation of ordered logistic regression comments

\begin{tabular}{|c|c|c|c|c|c|c|c|}
\hline Incorporation & \multicolumn{2}{|c|}{ Model 01} & Model 02 & \multicolumn{2}{|c|}{ Model 03} & Model 04 & Model 05 \\
\hline \multicolumn{8}{|c|}{ 1. Group variables } \\
\hline \multirow[t]{2}{*}{ Business community } & $0.771^{*}$ & $0.887^{*}$ & 0.530 & 0.303 & 0.151 & 0.137 & 0.558 \\
\hline & 0.365 & 0.440 & 0.402 & 0.402 & 0.443 & 0.636 & 0.387 \\
\hline \multirow[t]{2}{*}{ State actors } & $0.943^{*}$ & $1.060^{*}$ & 0.702 & 0.571 & 0.630 & 0.805 & -0.081 \\
\hline & 0.371 & 0.466 & 0.477 & 0.482 & 0.598 & 0.441 & 1.021 \\
\hline \multirow[t]{3}{*}{ Individuals } & -0.151 & & & & & & \\
\hline & 0.496 & & & & & & \\
\hline & & 2. Comr & t character & & & & \\
\hline \multirow[t]{2}{*}{ Technicality } & & & $0.698^{* *}$ & & & 0.461 & $0.619^{*}$ \\
\hline & & & 0.253 & & & 0.360 & 0.262 \\
\hline \multirow[t]{2}{*}{ Log (words) } & \multicolumn{7}{|c|}{$0.644^{* * *}$} \\
\hline & \multicolumn{7}{|c|}{0.131} \\
\hline \multirow[t]{2}{*}{ Log (propositions) } & & & & & $1.705^{* *}$ & & \\
\hline & & & & & 0.235 & & \\
\hline \multirow[t]{2}{*}{ Economic } & & & 0.498 & 0.057 & 0.187 & 0.467 & 0.493 \\
\hline & & & 0.398 & 0.261 & 0.303 & 0.402 & 0.406 \\
\hline \multirow[t]{2}{*}{ Legal } & & & 0.121 & -0.076 & -0.531 & 0.125 & 0.122 \\
\hline & & & 0.392 & 0.437 & 0.496 & 0.385 & 0.392 \\
\hline \multirow[t]{2}{*}{ Regulatory } & & & -0.112 & -0.220 & -0.358 & -0.088 & -0.106 \\
\hline & & & 0.279 & 0.233 & 0.240 & 0.297 & 0.268 \\
\hline \multicolumn{8}{|c|}{ 3. Interactions } \\
\hline \multirow{2}{*}{$\begin{array}{l}\text { Business community } \mathrm{x} \\
\text { Technicality }\end{array}$} & & & & & & 0.460 & \\
\hline & & & & & & 0.403 & \\
\hline \multirow{2}{*}{$\begin{array}{l}\text { State actors x } \\
\text { Technicality }\end{array}$} & & & & & & & 0.734 \\
\hline & & & & & & & 0.717 \\
\hline \multirow[t]{2}{*}{ Cutt 1} & 0.538 & 0.655 & $1.174^{*}$ & $4.234^{* * *}$ & $2.256^{* * *}$ & 1.009 & 1.119 \\
\hline & 0.279 & 0.420 & 0.582 & 1.028 & 0.589 & 0.632 & 0.595 \\
\hline \multirow[t]{2}{*}{ Cutt 2} & $0.818^{* *}$ & $0.934^{*}$ & $1.471^{*}$ & $4.555^{* * *}$ & $2.627^{* * *}$ & $1.307^{*}$ & $1.417^{*}$ \\
\hline & 0.303 & 0.445 & 0.613 & 1.080 & 0.640 & 0.667 & 0.625 \\
\hline
\end{tabular}

Source: Dataset: Banco_Dados_Baird_Fernandes

Obs.1: ${ }^{*} \mathrm{p}<0.05,{ }^{* *} \mathrm{p}<0.01,{ }^{* * *} \mathrm{p}<0.00 \mid$ Obs.2: $\mathrm{N}=518$ | Obs.3: standard errors clustered by regulation

Graph 1. Probability of incorporation due to comment technicality.

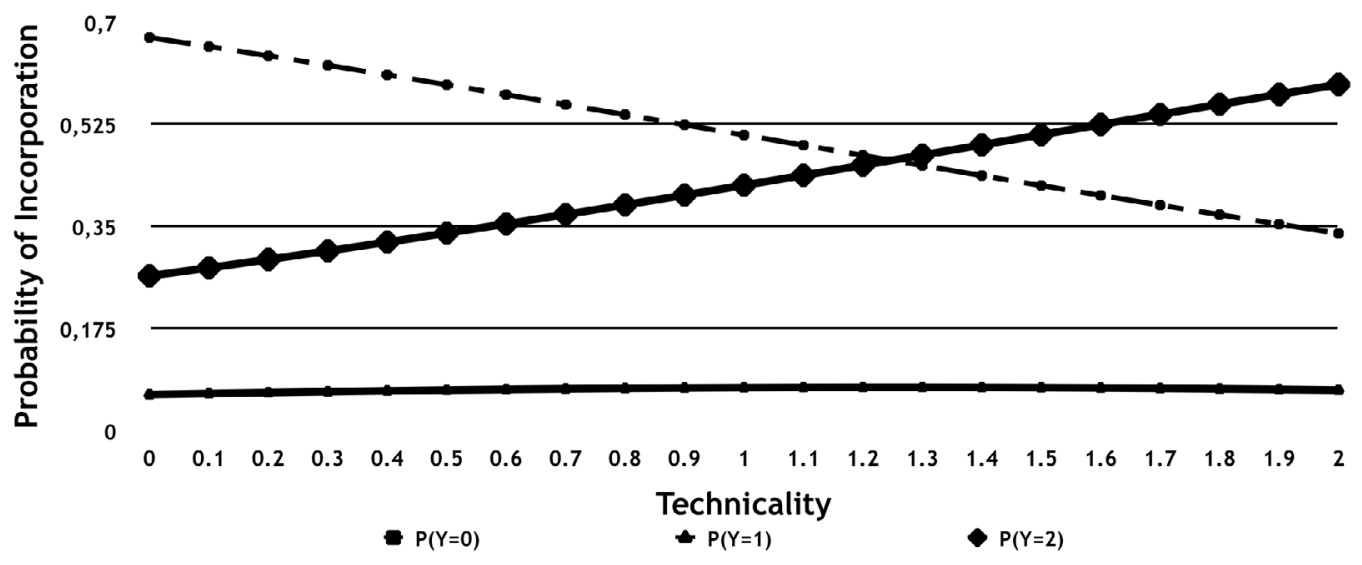




\section{Binary logistic model}

In Table 10, we present the results of the logistic model. Like before, we identified the interest groups in the first model, having organized civil society and the group of comments from individuals as baseline. The result is surprising, because only the public sector was statistically significant. Business community interest groups do not appear different from the baseline, although they are at the limit of 'not significant'. In the second model, we incorporate the variables that characterize the comments, namely: technicality, economic, legal and regulatory. Again the results indicate that the relevant variable is the comment technicality ${ }^{8}$. The results are more evident when measuring technicality according to the number of words or the number of proposals in each of the comments, which is the third model presented in columns 3 and 4.

In the fourth and fifth models, we again verify whether the relationship between technicality and interest group is stronger when the variables interact. As we can see in Table 10, the interactions between technicality and public sector and between technicality and business community sector are not different from zero, indicating that ANAC does not respond differently to technical arguments coming from different types of interest groups. Thus, there is no prevalence of any interest group at ANAC public hearings. The higher incorporation rates of actors from the public sector and the business community sector does not seem to be justified by any supposed bias towards these groups, but to be due to these sectors producing the most qualified comments. Repeating the analysis in Figure 2, it is once again clear that increasing technical sophistication of the argument implies an increased likelihood of comment incorporation.

In this paper we presented five research hypothesis. The empirical results show that only Hypothesis 1 is supported. The best results at ANAC public hearings, obtained by state actors and the business community, do not reflect the fact that these groups possess greater influence on the regulatory agency, but reflect rather the propensity of ANAC to incorporate comments of a technical nature. As we have seen, it was precisely these groups that have produced the most technical arguments over these six years (2007-2012).

There was not sufficient evidence to support hypothesis $2,3,4$ and 5 . In relation to the first two, the fact that the arguments are of economic or legal nature does not increase the likelihood of comment incorporation. Regarding the third hypothesis, once the comment quality has been verified, we find no evidence that business groups benefit vis-à-vis the other social groups at this stage of the decision process. Hypothesis 5 was refuted, moreover, because the statistical non-significance of the interactions showed that technical arguments presented by the business community groups are not privileged in comparison to technical comments from other interest groups.

We demonstrate, however, that, at least in ANAC public hearings held between 2007 and 2012, there is no evidence of capture theory on the part of business interests. At this moment in the decision process, what seems to guide the changes in the proposed resolutions is the quality of argumentation aimed at perfecting the regulation written by the regulatory agency.

8 The same result stands if the technicality variable is computed as a dummy indicating that the comment is 0 (neither technical nor exhaustive) and 1 (exhaustive). 
Table 10. Incorporation of binary logistic regression comments

\begin{tabular}{|c|c|c|c|c|c|c|}
\hline Incorporation & Model 01 & Model 02 & \multicolumn{2}{|c|}{ Model 03} & Model 04 & Model 05 \\
\hline \multicolumn{7}{|c|}{ 1. Group variables } \\
\hline \multirow[t]{2}{*}{ Business community } & 0.979 & 0.608 & 0.366 & 0.213 & -0.034 & 0.641 \\
\hline & 0.502 & 0.476 & 0.483 & 0.538 & 0.492 & 0.458 \\
\hline \multirow[t]{2}{*}{ State actors } & $1.150^{*}$ & 0.736 & 0.577 & 0.712 & 0.910 & -0.048 \\
\hline & 0.532 & 0.532 & 0.550 & 0.702 & 0.492 & 1.104 \\
\hline \multicolumn{7}{|l|}{ Individuals } \\
\hline \multicolumn{7}{|c|}{ 2. Comment characteristics } \\
\hline \multirow[t]{2}{*}{ Technicality } & & $0.676^{*}$ & & & 0.302 & $0.591^{*}$ \\
\hline & & 0.277 & & & 0.368 & 0.296 \\
\hline \multirow[t]{2}{*}{ Log (words) } & & & $0.671^{* * *}$ & & & \\
\hline & & & 0.144 & & & \\
\hline \multirow[t]{2}{*}{ Log (propositions) } & & & & $1.735^{* * *}$ & & \\
\hline & & & & 0.266 & & \\
\hline \multirow[t]{2}{*}{ Economic } & & 0.278 & -0.220 & -0.174 & 0.233 & 0.265 \\
\hline & & 0.371 & 0.244 & 0.266 & 0.374 & 0.384 \\
\hline \multirow[t]{2}{*}{ Legal } & & 0.272 & 0.064 & -0.328 & 0.277 & 0.279 \\
\hline & & 0.391 & 0.429 & 0.492 & 0.387 & 0.393 \\
\hline \multirow[t]{2}{*}{ Regulatory } & & 0.110 & 0.009 & -0.018 & 0.159 & 0.120 \\
\hline & & 0.236 & 0.192 & 0.209 & 0.253 & 0.226 \\
\hline \multicolumn{7}{|c|}{ 3. Interactions } \\
\hline \multirow{2}{*}{$\begin{array}{l}\text { Business community } \mathrm{x} \\
\text { Technicality }\end{array}$} & & & & & 0.736 & \\
\hline & & & & & 0.419 & \\
\hline \multirow{2}{*}{$\begin{array}{l}\text { State actors } \mathrm{x} \\
\text { Technicality }\end{array}$} & & & & & & 0.717 \\
\hline & & & & & & 0.709 \\
\hline \multirow[t]{2}{*}{ Constant } & $-1.001^{*}$ & -1.512 & $-4.772^{* * *}$ & $-2.726^{* * *}$ & -1.254 & $-1.453^{*}$ \\
\hline & 0.509 & 0.694 & 1.248 & 0.740 & 0.709 & 0.707 \\
\hline
\end{tabular}

Source: Dataset: Banco_Dados_Baird_Fernandes

Obs.1: ${ }^{*} \mathrm{p}<0.05,{ }^{* *} \mathrm{p}<0.01,{ }^{* * *} \mathrm{p}<0.00 \mid$ Obs.2: $\mathrm{N}=518$ | Obs.3: standard errors clustered by regulation

Graph 2. Probability of incorporation due to technicality of the comment.

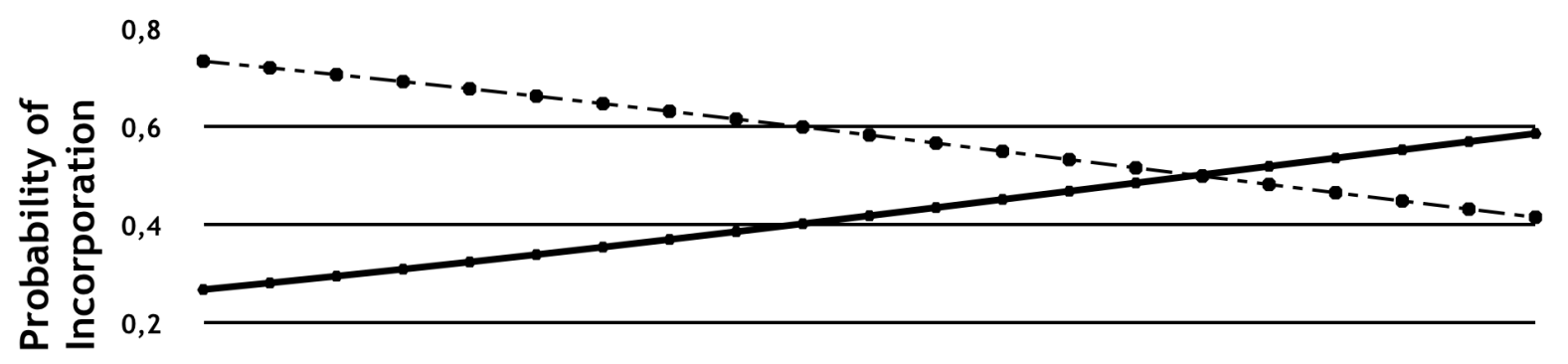

0

$\begin{array}{lllllllllllllllllllll}0 & 0.1 & 0.2 & 0.3 & 0.4 & 0.5 & 0.6 & 0.7 & 0.8 & 0.9 & 1 & 1.1 & 1.2 & 1.3 & 1.4 & 1.5 & 1.6 & 1.7 & 1.8 & 1.9 & 2\end{array}$

- $P(Y=0)$ 


\section{Conclusions}

Political scientists in Brazil have become increasingly interested in the subject of regulatory agencies. We saw, however, that there is still little effort being made to analyze the political actions and influence of lobbyists on regulatory agencies. The present study adds to this promising literature and seeks to make a contribution towards a better understanding of the role of interest groups and their impact on public hearings.

It is important to note that the method of measuring the impact of the interest groups action is based on their formal participation in public hearings. We do not intend to cover all of the influence exerted by the groups, which could only be done through a close examination of their actions by the ANAC beyond participation mechanisms provided by the regulatory agency and a broader analysis that would take into account the role of other political arenas possibly triggered by these groups, such as other bodies of the Executive Branch and the Legislative Branch.

Our analysis of ANAC public hearings revealed, as did the work of Silva concerning ANEEL (2012), predominance in the participation of the business community. This result was expected, in that it concerns an industry, the civil aviation sector, which is characterized by the presence of strong business groups. On the other hand, the technicality of the discussions tended to reduce the participation of a wider range of social actors. It should be emphasized that the participation of individuals was significant. Moreover, it is difficult to determine an optimal level of participation for the various social groups.

The rate of comment incorporation also follows a pattern similar to the study by Silva (2012). Summing the categories "accepted" and "partially accepted" for the ANEEL comment contributions, we found that the overall comment incorporation rate was at $40.1 \%$, similar to the rate found in our study: $41.1 \%$. Another interesting pattern to be noted is in the groups whose comments are incorporated the most by regulatory agencies. We identified that state actors, followed by the business community actors, are the participants who are most likely to be recognized by ANAC, a dynamic which was also observed in Silva's study (2012).

Brazilian literature on the subject therefore begins to draw certain conclusions about the involvement and impact of social groups at regulatory agencie's public hearings. First of all, there seems to be predominance in business community participation. Secondly, the regulatory agencies consider the participation of social groups to be relevant, which is expressed by a relatively high level of incorporation, or at least partial incorporation, of their comments. Thirdly, it should be noted that public institutions are important participants in this process, and usually have their demands met in good measure.

This brings us to the final point, which is perhaps the main and most original contribution of our work, which is to understand why some interest group contributions have more influence on the decisions made by ANAC following the public hearings.

Our analysis showed that the main reason why comments are incorporated into the final text of regulations is directly related to their technical nature. Thus, comments which are greatly technical in nature and serve to subsidize the discussion and to improve the text under scrutiny are more likely to be incorporated by the regulatory agency. Despite the power of the business community and the strength of their participation, the technical quality of the comment is the main factor in explaining the rate of comment incorporation used by ANAC.

This finding is entirely consistent with the role of public hearings, as per analysis by Gonzalo Vecina Neto, first president of the National Health Surveillance Agency - ANVISA. According to him, there are two basic functions that must be met by this expedient: 
On one hand, to legitimize the process triggered by regulatory agencies. On the other hand, to collect the technical information necessary for the regulatory agency's performance, even if it means imposing economic losses on the regulated sector. To quote Gonzalo Vecina Neto:

It (the public hearing) will actually impose a new behavior for the market. What, then, is its purpose? To find out if it is lacking in knowledge. Bring in the light of knowledge. Exposed to the light of knowledge, decisions can be made in a technical and legal manner. Not so much in a social manner, because many laws end up having a significant economic burden on the industry (VECINA NETO, 2012).

We are advancing on various aspects in the literature on regulatory agencies and interest groups, finding patterns in the interaction between these groups and regulatory agencies. However, only further studies will allow us to focus on unanswered questions in this discussion, such as the areas of public policy where there is greater or lesser participation; where there is more or less balance in this participation and under what circumstances and in what areas the regulatory agencies tend to be more responsive to interest groups. Likewise, studies that go beyond the scope of public hearings and take into account a broader list of strategies and political arenas driven by interest groups (BAIRD, 2012) can be very useful in divulging all of the influence exerted by these groups.

Translated by Ruth Hollard Submitted in June 2013 Accepted in April 2014

\section{References}

ALVES, Sandra Mara C. (2008), Processo de participação da sociedade civil nas consultas públicas realizadas pela Agência Nacional de Vigilância Sanitária - Anvisa $(2000$ - 2006). UNB, Brasília, Dissertação de Mestrado.

BACHRACH, Peter and BARATZ, Morton S. (1962), Two Faces of Power. The American Political Science Review, Vol. 56, Issue 4 (Dezembro, 1962), pp. 947-952.

BAIRD, Marcello Fragano (2012), O Lobby na Regulação da Propaganda de Alimentos da Agência Nacional de Vigilância Sanitária - Anvisa. USP, São Paulo, Dissertação de Mestrado.

BAIRD, Marcello Fragano (2011), Gênese e Constituição da Anvisa: O Jogo Político da Política Regulatória no Setor de Vigilância Sanitária. Paper apresentado no XXXV EnANPAD, Rio de Janeiro, 04-07/09/2011.

BALLA, Steven J. (1998), Administrative Procedures and Political Control of the Bureaucracy. The American Political Science Review, Vol. 92, № 03, (Sep., 1998), pp. 663- 673.

BAUMGARTNER, Frank R. and LEECH, Beth L. (1998), Basic Interests: The Importance of Groups in Politics and in Political Science. Princeton University Press - Princeton, New Jersey.

CABRAL, Eugênia (2007), Articulação de interesses do empresariado industrial no processo de produção da regulação ambiental: convergências e divergências. Universidade Federal de Minas Gerais, Tese de Doutorado.

CARDOSO, Fernando Henrique (1975), Autoritarismo e Democratização. Paz e Terra. Rio de Janeiro.

CARRIGAN, Christopher; COGLIANESE, Cary (2011), The Politics of Regulation: From New Institutionalism to New Governance. Annual Review of Political Science. Vol. 14, pp.107-29.

COSTA, Valeriano Mendes Ferreira (2002), A dinâmica institucional da reforma do Estado: um balanço do período FHC. In: Abrucio, Fernando e Maria Rita Loureiro (org.), O Estado numa Era de Reformas: os Anos FHC. Versão eletrônica: Brasília, SEGES-MP.

DINIZ, Eli and BOSCHI, Renato (2004), Empresários, interesses e mercado: dilemas do desenvolvimento no Brasil. Belo Horizonte, Ed. UFMG. 
FERNANDES, Ivan Filipe de Almeida Lopes (2011), Burocracia e Política. A construção institucional da política comercial brasileira. Biblioteca 24horas. 1ª edição. São Paulo.

FRITSCHLER, A. Lee (1969), Smoking and Politics: Policymaking and the Federal Bureaucracy. Meredith Corporation.

GOLDEN, Marissa Martino (1998), Interest Groups in the Rule-Making Process: Who Participates? Whose Voices Get Heard? Journal of Public Administration Research and Theory. Vol.08, №2, pp. 245- 70.

HECLO, Hugh (1978), Issue Networks and the Executive Establishment. In: The New American Political System. Edited by Anthony King. Washington, DC.: American Enterprise Institute.

KELLEHER, Christine A. and YACKEE, Susan Webb (2006), Who's Whispering in Your Ear? The Influence of Third Parties Over State Agency Decisions. Political Research Quarterly. Vol. 59, № 04, (December), pp. 629-643.

KERWIN, Cornelius M. (1996), Normatização: como entidades governamentais escrevem leis e fazem política. Rio de Janeiro: Nórdica.

MANCUSO, Wagner Pralon (2007), O lobby da indústria no Congresso Nacional: empresariado e política no Brasil contemporâneo. São Paulo: Humanitas, Edusp.

MATTOS, Paulo (2004), Regulação econômica e social e participação pública no Brasil. In:Vera Schattan P. Coelho e Marcos Nobre (org.), Participação e deliberação: teoria democrática e experiências institucionais no Brasil contemporâneo. São Paulo, Editora 34.

McKAY, Amy and YACKEE, Susan Webb (2007), Interest Group Competition on Federal Agency Rules. American Politics Research. Vol. 35, № 03, May 2007, pp. 336-357.

MOE, Terry M. (1987) Interests, Institutions, and Positive Theory: The Politics of the NLRB. Studies of American Political Development. New Haven: Yale University Press.

NAUGHTON, Keith; SCHMID, Celeste; YACKEE, Susan Webb and ZHAN, Xueyong (2009), Understanding Commenter Influence During Agency Rule Development. Journal of Policy Analysis and Management, Vol. 28, № 02, pp. 258-277.

NELSON, David and YACKEE, Susan Webb (2011), Lobbying Coalitions and Government Policy Change: An Analysis of Federal Agency Rulemaking. The Journal of Politics, Vol. 74, № 01, January 2011, pp. 1-15.

NUNES, Edson (1997), A gramática política do Brasil: clientelismo e insulamento burocrático no Brasil. Rio de Janeiro: Jorge Zahar Editor.

NUNES, Edson (2001), O Quarto Poder - Gênese, contexto perspectivas e controle das agências reguladoras. Paper do II Seminário Internacional sobre Agências Reguladoras de Serviços Públicos. Instituto Hélio Beltrão, Brasília, 25 de setembro de 2001.

NUNES, Edson; NOGUEIRA, André; COSTA, Cátia; ANDRADE, Helenice and RIBEIRO, Leandro (2007), Agências reguladoras e reforma do Estado no Brasil: inovação institucional e continuidade no sistema políticoinstitucional. Rio de Janeiro: Garamond.

OLSON, Mancur (1999), A lógica da ação coletiva: os benefícios públicos e uma teoria dos grupos sociais. São Paulo: Editora da Universidade de São Paulo.

PACHECO, Regina Silvia (2006), Regulação no Brasil: desenho das agências e formas de controle. RAP Revista de Administração Pública, Vol. 40, № 04, pp. 523-43.

PETERS, Guy (1995), The Politics of Bureaucracy. London. Longman Publishers. 4 a Edição.

PIOVESAN, Márcia Franke (2002), A Construção Política da Agência Nacional de Vigilância Sanitária. Fundação Oswaldo Cruz, Escola Nacional de Saúde Pública, Rio de Janeiro, Dissertação de Mestrado.

PÓ, Marcos Vinicius (2004), A Accountability no modelo regulatório brasileiro: gênese e indefinições (os casos da ANATEL e ANS). FGV, São Paulo, Dissertação de Mestrado.

PÓ, Marcos Vinicius (2009), 0 jogo regulatório brasileiro: a estabilidade contratual par além da autonomia das agências. FGV, São Paulo, Tese de Doutorado.

PÓ, Marcos Vinicius and ABRUCIO, Fernando Luiz (2006), Desenho e funcionamento dos mecanismos de controle e accountability das agências reguladoras brasileiras: semelhanças e diferenças.Rev. Adm. Pública. Vol. 40, № 04, Jul/Ago, Rio de Janeiro.

SCHMITTER, Philippe C. (1971), Interest Conflict and Political Change in Brazil. Stanford University Press.

SELZNICK, Philip (1949), TVA and the Grass Roots. Berkeley: University of California Press. 
SILVA, Mariana Batista (2011a), o Desenho Institucional em Prática: uma análise da independência das agências regulatórias brasileiras (1997-2009). V Prêmio SEAE de Monografias em Defesa da Concorrência e Regulação Econômica. 1ํe ed. Brasília: SEAE/Ministério da Fazenda.

SILVA, Rodrigo Brandão (2011b), Órgãos reguladores autônomos e política de nomeações: o caso do Conselho Administrativo de Defesa Econômica. USP, São Paulo, Dissertação de Mestrado.

SILVA, Mariana Batista (2012), Mecanismos de participação e Atuação de Grupos de Interesse no Processo Regulatório Brasileiro: o caso da Agência Nacional de Energia Elétrica (ANEEL). Revista de Administração Pública, vol. 46, no 4, Rio de Janeiro, July/August/2012.

STIGLER, George (1975), The Theory of Economic Regulation. In: The Citizen and the State: Essays on Regulation. The University of Chicago Press: pp. 114-144.

TAGLIALEGNA, Gustavo H. Fidelis and CARVALHO, Paulo Afonso F. de (2006), Atuação de grupos de pressão na tramitação do projeto de lei de biossegurança. Revista de Informação Legislativa, Senado Federal, Vol. 43, № 169, p. 161-188, jan./mar. 2006, Brasília.

WEINGAST, Barryand MORAN, Mark(1983),BureaucraticDiscretion orCongressional Control? Regulatory Policymaking by the Federal Trade Commission. Journal of Political Economy, Vol. 91, № 05 (Oct., 1983), pp. 765-800.

WEST, William F. (2004), Formal Procedures, Informal Processes, Accountability, and Responsiveness in Bureaucratic Policy Making: An Institutional Policy Analysis. Public Administration Review, Vol. 64, № 01, January/February 2004.

WEST, William F. (2005), Administrative Rulemaking: An Old and Emerging Literature. Public Administration Review, Vol. 65, № 06 , November/December 2005.

WOOLDRIDGE, Jeffrey M. (2002), Econometric Analysis of Cross Section and Panel Data. The MIT Press.

YACKEE, Susan Webb (2005), Sweet-Talking the Fourth Branch: The Influence of Interest Group Comments on Federal Agency Rulemaking. Journal of Public Administration Research and Theory, Vol. 16, pp.103-124.

YACKEE, Jason Webb and YACKEE, Susan Webb (2006), A Bias Towards Business? Assessing Interest Group Influence on the U.S. Bureaucracy. The Journal of Politics, Vol. 68, № 01, February 2006, pp. 128-139. 